\title{
CALCIUM HYDROXIDE: STUDY BASED ON SCIENTIFIC EVIDENCES
}

\author{
HIDRÓXIDO DE CÁLCIO: ESTUDO BASEADO EM EVIDÊNCIAS CIENTÍFICAS
}

Carlos ESTRELA

Chairman and Professor of Endodontics, Federal University of Goiás, Goiânia, GO, Brazil.

Roberto HOLLAND

Chairman and Professor of Endodontics, Faculty of Dentistry of Araçatuba, UNESP, Araçatuba, SP, Brazil.

\begin{abstract}
7 he characteristics of calcium hydroxide come from its dissociation into calcium and hydroxyl ions. The action of these ions on tissues and bacteria explains the biological and antimicrobial properties of this substance. Under the conditions of this retrospective of literature, based on scientific evidences, it is possible to state that: 1 . Dentin is considered the best pulpal protective, and calcium hydroxide has proved, through numerous studies, its capability of inducing the formation of a mineralized bridge over pulpal tissue. 2. It is necessary, whenever possible, to provide time for calcium hydroxide paste to manifest its potential of action on the microorganisms present in endodontic infections. The maintenance of a high concentration of hydroxyl ions can change bacteria enzymatic activity and promote its inactivation. 3 . The site of action of hydroxyl ions of calcium hydroxide includes the enzymes in the cytoplasmic membrane. This medication has a large scope of action, and therefore is effective on a wide range of microorganisms, regardless their metabolic capability. In microbial world, cytoplasmic membranes are similar, irrespective from microorganisms morphological, tinctorial and respiratory characteristics, which means that this medication has a similar effect on aerobic, anaerobic, Gram-positive and Gram-negative bacteria. 4. Calcium hydroxide as temporary dressing used between appointments promotes better results on the periapical healing process than the treatment in one appointment.
\end{abstract}

UNITERMS: Calcium hydroxide; Dental pulp cavity; Intracanal medication; Mineral trioxide agregate; Portland cement.

\section{INTRODUCTION}

Calcium hydroxide has been studied for many years. Herman $^{38}$ in 1920 suggested calcium hydroxide for the treatment of dental pulp. The formula (Calxyl-Otto \& CO; Frankfurt, Germany) was considered to be the pioneer in the use of calcium hydroxide, with addition of others substances. For Stanley ${ }^{115}$ a new era had begun. Calcium hydroxide encourages the deposition of a hard tissue bridge that usually protects the dental pulp ${ }^{34,43}$. The ability to stimulate mineralization associated to the antimicrobial effectiveness confers on it the current success as an endodontic medication.

However, well-conducted researches about the properties of calcium hydroxide, such as histocompatibility, antimicrobial potential, physical-chemical aspects, give credibility to the choice of this medication in several clinical situations $^{1-123}$.

Scientific research on calcium hydroxide indications in endodontic does not mean: habits of prescription, beliefs in beneficial effects or even the attempt to determine a drug able to heal all illnesses. It is only necessary to establish appropriate criteria for use, including limits and implications and, at the same time, show the value of research to explain facts that are not yet clear or are mistakenly explained ${ }^{23}$.

Calcium hydroxide is an excellent therapeutic option when the clinical situation requires the use of pulp capping agent and intracanal medication. Two effects of this medication need to be considered, biological and antimicrobial effects ${ }^{5,30,31}$. Thus, others factors can alter this effects, like the influence of vehicles in this properties and the time of action for to express microbial control ${ }^{3,6-8,11-13,15-}$ 27,29-32,35,37,42,44,60,81,82,105,110,117. Other substances with objectives similar to calcium hydroxide, like Mineral Trioxide Agregate and Portland cement, have also been studied $9,76,78,79,88,89,94,99,100,108,113,119,120,123$.

Before the discussion of essential topics it's important to analyze calcium hydroxide indications in endodontics. In the dental pulp, calcium hydroxide has been used as a pulp capping agent because of its ability to stimulate mineralization ${ }^{40,43,45,46}$; as intracanal dressing it has excellent antimicrobial action $3,7,13,47,62,106,107,117$, that favor to eliminate 
microorganisms after cleaning and shaping, to neutralize the remaining toxins $\mathrm{s}^{2,106,107}$, besides maintaining the temporary sealing.

Calcium hydroxide has been questioned about its real effectiveness at dental pulp treatment and as an intracanal medication. However, a large number of studies have showed its benefits ${ }^{3,5-32,38-92}$. Today, calcium hydroxide is the most common endodontic medication used, and its efficacy has been proved by scientific researches and its regular use along the time ${ }^{38,61,62}$.

The chemical dynamics of calcium hydroxide as demonstrated by ionic dissociation, characterizes its properties. The activation of tissue enzymes such as alkaline phosphatase shows mineralizing effects and inhibiting effect on bacterial enzymes, which leads to its antimicrobial property, illustrating the biological qualities of hydroxyl and calcium ions on both tissue and microorganisms ${ }^{30,31}$.

Considering the importance of calcium hydroxide in dentistry, a big landmark was Herman's ${ }^{38}$ pioneer studies. This study discusses, based on scientific evidences, its main functions, with special attention to maintain endodontic biological principles.

\section{BIOLOGICAL EFFECT}

Calcium hydroxide is a strong base obtained through calcination (heating) of calcium carbonate until its transformation into calcium oxide. Calcium hydroxide is obtained through the hydration of calcium oxide and the chemical reaction between calcium hydroxide and carbon dioxide forms calcium carbonate. It is a white powder with a high $\mathrm{pH}$ (12.6) and is slightly soluble in water (solubility of $1.2 \mathrm{~g} / \mathrm{L}$, at a temperature of $\left.25^{\circ} \mathrm{C}\right)^{36}$.

The properties of calcium hydroxide come from its dissociation into calcium and hydroxyl ions and the action of these ions on tissues and bacteria explains biological and antimicrobial properties of this substance. Changes in the biological properties can also be understood through the chemical reactions, since calcium hydroxide, in the presence of carbon dioxide, becomes calcium carbonate (weak acid oxide) and this product does not have calcium hydroxide's biological properties such as the mineralizing capability ${ }^{30}$.

Estrela, Pesce ${ }^{24}$ chemically analyzed the release of calcium and hydroxyl ions from calcium hydroxide pastes in connective tissue of a dog, by means of conductimeter analysis. The vehicles had different acid-base and hydrosolubility characteristics (saline, anesthetic and polyethylene glycol 400). The release of hydroxyl ions from the pastes can be demonstrated by the release of calcium ions and hydroxyl ions and the molecular weight of calcium hydroxide. In calcium hydroxide the ratio of hydroxyl ions and calcium ions is $45.89 \%$ and $54.11 \%$. The percentage values of calcium and hydroxyl ions released by calcium hydroxide pastes over a period of 7, 30, 45 and 60 days are reported in Graphics 1 - 2.

The formation of calcium carbonate in connective tissue of dogs showed that when saline vehicle is used with calcium hydroxide the formation rate of calcium carbonate is practically unaltered after 30 days up to 60 days (Graphic 3 ). The values in mass of calcium carbonate are small, with an increase up to 30 days and stabilizing at 30-60 days. Thus, after the initial reaction of calcium hydroxide with tissue, a reduction in the number of changes of the intracanal medication is indicated, especially after initial inflammatory symptoms. The characteristics of calcium hydroxide resulting from ionic liberation are directly influenced by carbon dioxide which, by forming a weak acid oxide, could cause a partial neutralization of the medication that is basic $\mathrm{c}^{25}$.

The chemical analysis of essential aspects of the

LIBERATED CALCIUM IONS (\%)

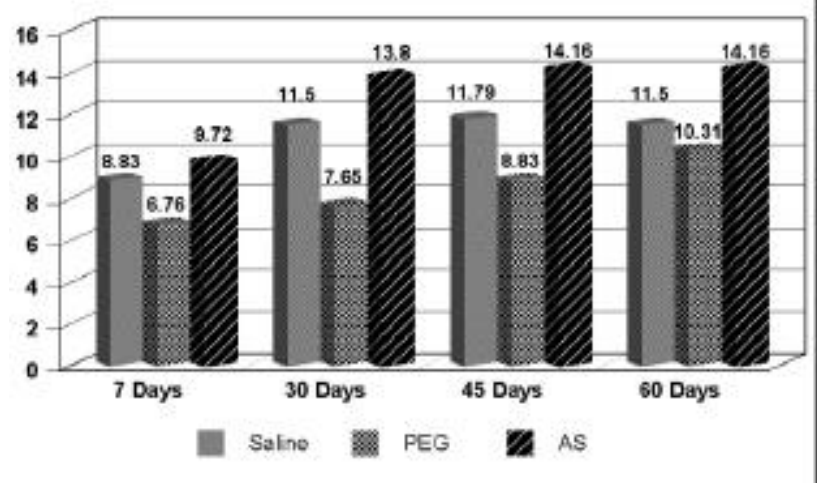

GRAPHIC 1- Release calcium ions ${ }^{24}$

LIBERATED HYDROXYL IONS (\%)

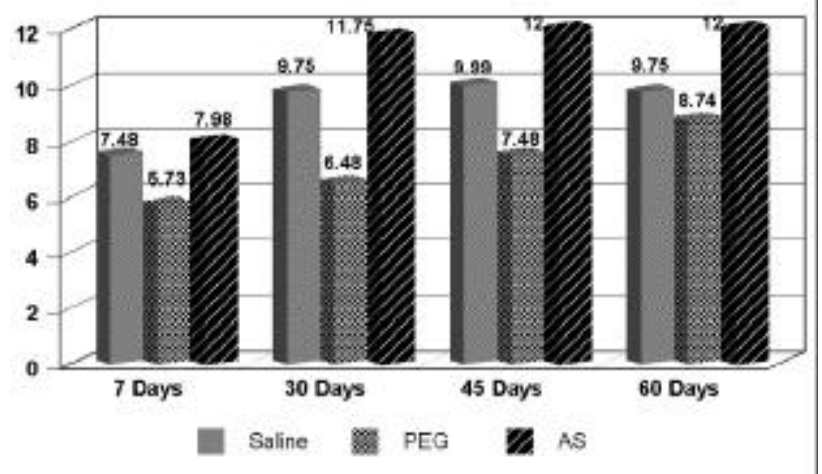

GRAPHIC 2- Release hydroxyl ions ${ }^{24}$

FORMATION RATE OF $\mathrm{CaCO}_{3}(\mathrm{~g} / \mathrm{L})$

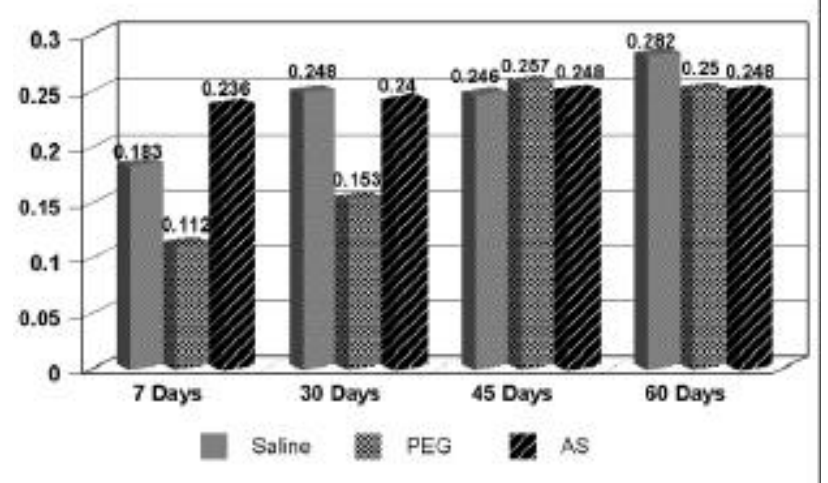

GRAPHIC 3- Formation rate of $\mathrm{CaCO}_{3}(\mathrm{~g} / \mathrm{L})^{25}$ 
substance is important in order to use it correctly, i.e., the influence of vehicle on the rate of ionic dissociation; the time necessary for dentinal diffusion and for reaching the appropriate $\mathrm{pH}$ level for microbial control and the level of resorption; the action of carbon dioxide from tissue and atmosphere that favors the transformation of calcium hydroxide into calcium carbonate and interferes in the mineralizing and antimicrobial effects, making necessary intracanal dressing changes; the antimicrobial effect of vehicle and calcium hydroxide paste.

Calcium hydroxide has the capability of activating tissue enzymes such as alkaline phosphatase, which favor tissue restoration through mineralization. The optimum $\mathrm{pH}$ value for the activation of this enzyme ranges from 8.6 to 10.3, what makes the release of organic phosphate (phosphate ions) which reacts with calcium ions from the circulating blood easier, creating a sediment of calcium phosphate on the organic matrix ${ }^{118}$. Indeed, this sediment is the molecular unit of hydroxyapatite. Several studies showed that calcium hydroxide participate in the hard tissue bridge formation $^{5,40,41,45,46,49-51,63-70,73,74,98,102,114,116}$.

A few minutes after the contact of pulp tissue with calcium hydroxide, the formation of necrotic areas begins ${ }^{5}$. Right at the limit between the live and necrotic tissue there is calcium salts deposition, whereas dentine is observed about 15 days after treatment ${ }^{5,43}$. Calcium hydroxide in direct contact with conjunctive tissue originates a zone of necrosis, altering the physical-chemical status of intercellular substance which, through rupture of glycoproteins, seems to determine proteic denaturation ${ }^{43}$.

The formation of mineralized tissue after contact of calcium hydroxide with conjunctive tissue has been observed from about the 7 th to the 10 th day ${ }^{1,43}$. Holland ${ }^{43}$ studying the healing process of dental pulp after pulpotomy with calcium hydroxide, verified the existence of massive granulation in the superficial granulosis zone interposed between the necrosis zone and the deep granulosis zone. He went on to report that these structures are made up of calcium salts and calcium-protein complexes. They show themselves to be birefringent to polarized light, reacting positively to chloranic acid and to Von Kossa's method, proving that part of the calcium ions come from the protective material. Below the deep granulation zone there are the proliferation cellular zone and the normal pulp. Similar results were obtained by Seux et al. ${ }^{109}$.

Other hydroxides were also evaluated regarding their effects on pulpal tissue. Holland et al.$^{63}$ evaluated the effect of calcium hydroxide, barium hydroxide and strontium hydroxide after pulp capping through histochemical analysis in dog dental pulp. The results were similar among the three hydroxides and showed deposits of strontium carbonate and barium carbonate grains resembling the graining observed with calcium hydroxide. Since barium and strontium are not naturally present in animals, these grainings originated from the capping material. They also reported that the presence of birefringent large grainings was not observed with the use of other hydroxides such as magnesium hydroxide, or sodium hydroxide, due to the fact that sedimentation only occurs with hydroxides whose solubility is similar to that of calcium hydroxide. Magnesium hydroxide is insoluble and sodium hydroxide is highly soluble in pulpal fluids. Barium hydroxide is slightly more soluble than strontium hydroxide, which can be observed through the fact that barium hydroxide grainings have been found deeper than strontium hydroxide grainings. This research confirms again the active participation of calcium ions from the calcium hydroxide of the protective material in the healing process.

Souza et al. ${ }^{114}$ after morphological study of the dental pulp behavior after pulpotomy followed by protection using magnesium oxide or calcium hydroxide, reported that the possibility of restoration using magnesium oxide was remote. The efficacy of the treatment in pulps protected with calcium hydroxide was higher, which eliminated the occurrence of technical failure during the treatment with magnesium oxide.

Mello et $a l .{ }^{98}$ analyzed the dental pulp response to calcium hydroxide and to zinc oxide-eugenol paste handled in two different consistencies. After 30 days, the histological examination showed that the dental pulp response to zinc oxide-eugenol was an inflammatory infiltration added to the absence to healing. The capping with calcium hydroxide exhibited in all specimens healing process that was characterized by dentin deposition in a continuous and complete bridge over the exposed pulp tissue. Various studies about pulp capping showed best results for calcium hydroxide when compared zinc oxide-eugenol. Markowitz et al..$^{97}$ related that high eugenol concentrations are cytotoxic. Direct application of eugenol to pulp tissue may result in extensive tissue damage.

In view of the biological and chemical evaluations of calcium hydroxide, it is possible to note its qualities as pulpal biological liner. Holland et al. ${ }^{49}$ studied the healing process of dog dental pulp after pulpotomy followed by pulpal protection using calcium hydroxide paste or powder. The results were analyzed histologically after 30 days of treatment. No difference between the experimental groups was observed and almost $90 \%$ of the specimens showed a bridge of completely mineralized tissue, protecting the vital dental pulps with no inflammation. Russo et al. ${ }^{102}$ verified the effects of the calcium hydroxide under pressure on the pulpal healing of pulpomized human teeth, and the microscopical analysis showed that no difference was observed between the groups. Regarding the post-pulpotomy healing process, Holland et al. ${ }^{68}$ carried out another study, analyzing pulpotomies and pulpal protection using calcium hydroxide or Dycal. The results showed that the mechanism of healing process of dental pulps protected with Dycal is similar to the one protected with calcium hydroxide, however the use of Dycal has lower efficacy.

Regarding the discussion about the mineralized barrier permeability, Holland et al. ${ }^{67}$ observed the formation of a hard tissue bridge after pulpotomy with calcium hydroxide. They performed pulpotomies on 80 monkey teeth using calcium hydroxide. After 30 days, the dressings of 60 teeth were removed, allowing the visualization of the hard tissue bridge. In order to evaluate permeability, the bridges were capped with silicate cement (20 teeth) or, zinc phosphate 
cement (20 teeth) and 20 teeth were exposed to the oral environment without any protection. The remaining 20 teeth were used as control. The pulpal responses of the experimental groups resembled the ones of the control group. The complete bridges showed a high level of normal remnant pulp. Fragments of dentin were found in the incomplete bridge. Despite of the belief of some researchers, the authors reported that these bridges were not permeable, and that the porosity was not a contraindication to the procedures of direct pulpal capping or pulpotomy.

Some authors criticize the quality of the hard tissue bridge formed with calcium hydroxide, claiming it may have tunnels defects, which can compromise the protecting efficiency of the bridge. Holland et al. ${ }^{46}$ discussed the tunnel defects observed on dentin bridges direct with the employment of calcium hydroxide. Human teeth indicated for extraction for orthodontics reasons were employed in this research. Their pulps were experimentally exposed and directly protected with the adhesive system Prime $\&$ Bond 2.1. One hundred and fifty days following the treatment the teeth were extracted and prepared for histological analysis. There were numerous tunnel defects in the neoformed dentin bridges, communicating the superior surface of the bridges with the pulp tissue. It was concluded, as admit Stanley, Palmeijer ${ }^{116}$, that the tunnel defects observed on dentin bridges have no relation with the material employed in direct pulp protection but with number and size of the vessels in this portion. Another experimental research in monkey teeth showed that a change of calcium hydroxide, after the formation of the hard tissue bridge, can promote new hard tissue deposition that repairs efficiently the tunnel defects of the bridge, if they exist ${ }^{45}$.

Costa et ll $^{4}$ evaluated the response of the pulp-dentin complex following application of a resin-modified glassionomer cement or an adhesive system in deep cavities performed in human teeth. Based on the experimental conditions, it was concluded total acid etching followed by application of one step bonding agent cannot be recommended as adequate procedures. In this clinical condition the cavity walls should be lined with a biocompatible dental material, such as Vitrebond or Dycal.

Recently a new cement has been developed - mineral trioxide aggregate (MTA), able to seal communications between the tooth and the external surfaces ${ }^{34}$. This material was studied in a series of in vivo and in vitro investigations, which reported good sealing ability ${ }^{120}$ and tissue behavior ${ }^{88,89}$. Formation of new cementum over the material was reported in experimentally perforated furcation ${ }^{99}$, in root end filling ${ }^{119}$ and root canal filling of dogs teeth ${ }^{89}$. Bridge-like dentin was observed in cases of pulp capping ${ }^{100}$ and pulpotomy ${ }^{113}$ in monkey and dog's teeth.

Holland et al. ${ }^{88}$ studied the reaction of rat connective tissue to implanted dentin tubes filled with MTA or calcium hydroxide, and observed similar results. In MTA groups, it was observed Von Kossa-positive granules, birefringent to polarized light. Next to these granulations, there was also irregular tissue like a bridge that was Von Kossa-positive. The dentin walls of the tube exhibited in the tubules a structure highly birefringent to polarized light, usually like a layer and at different depths. Similar results were reported for calcium hydroxide. It is possible that the mechanism of action of MTA, encouraging hard tissue deposit, is similar to that of calcium hydroxide.

Wucherpfenning, Green ${ }^{123}$ reported that both MTA and Portland cement seem almost identical macroscopically, microscopically and by X-ray defraction analysis. They reported that both substances support matrix formation in a similar fashion in cultures of osteoblast-like cells, and also as apposition of reparative dentin when used as direct pulp capping material in rat teeth.

Estrela et al. ${ }^{9}$ studied the antimicrobial and chemical properties of some materials, including MTA and Portland cement. The analyses of chemical elements present in MTA and in two samples of Portland cement were performed with a spectrometer of fluorescence of X-ray. They reported that Portland cement contains the same principle chemical elements as MTA, except that MTA also contains bismuth. They also reported that Portland cement had $\mathrm{pH}$ and antimicrobial activity similar to MTA. At the same time, Holland et al. ${ }^{78}$ observed at the rat subcutaneous connective tissue reaction to implanted dentin tubes filled with mineral trioxide aggregate, Portland cement or calcium hydroxide. The animals were sacrificed after 7 or 30 days and the undecalcified specimens were prepared for histological analysis with polarized light and Von Kossa technique for mineralized tissues. The results were similar for the studied materials. At the tube openings, there were Von Kossapositive granules that were birefringent to polarized light. Next to these granulations, there was an irregular tissue like a bridge that was Von Kossa-positive. The dentin walls of the tubes exhibited in the tubules a structure highly birefringent to polarized light, usually like a layer and at different depths. The mechanism of action of the studied materials has some similarity. In another study, Holland et $a l .{ }^{79}$ considering several reports about the similarity between the chemical compositions of the mineral trioxide aggregate and Portland cement, analyzed the behavior of dog dental pulp after pulpotomy and direct pulp protection with these materials. After pulpotomy, the pulp stumps of 26 roots of dog teeth were protected with MTA or Portland cement. Sixty days after treatment, the animal was sacrificed and the specimens removed and prepared for histomorphological analysis. There was a complete tubular hard tissue bridge in almost all specimens. In conclusion, MTA and Portland cement show similar comparative results when used in direct pulp protection after pulpotomy.

Holland et $a l .{ }^{79}$ found same results between gray and white MTA, indicating that the mechanisms of action are similar. The reaction of rat subcutaneous connective tissue to the implantation of dentin tubes filled with white mineral trioxide aggregate, a material that will be marketed. The tubes were implanted into rat subcutaneous tissue and the animals were sacrificed after 7 and 30 days. The undecalcified pieces were prepared for histological analysis with polarized light and von Kossa technique for mineralized tissues. Granulations birefring'ent to polarized light and an 
irregular structure like a bridge were observed next to the material; both were von Kossa positive. Also, in the dentin wall tubules a layer of birefringent granulations was observed.

Saidon et al. ${ }^{108}$ studied the cell and tissue reactions to mineral trioxide aggregate and Portland cement. The authors observed that MTA and Portland cement showed comparative biocompatibility when evaluated in vitro and in vivo. The results suggest that Portland cement has the potential to be used as a less expensive root-end filling material.

Transforming Growth Factors $\beta$ (TGF- $\beta$ ) - as Bone Morphogenetic Proteins (BPMs) has been investigated ${ }^{103,104,111,112}$ for use as direct pulp capping. At the moment, although calcium hydroxide promotes in the dental pulp a superficial necrosis, it encourages mineralization and maintains the pulp health ${ }^{5,43}$. Stanley, Pameijer ${ }^{116}$ reported that those practitioners continuing to use calcium hydroxide as a direct pulp-capping material, making certain that microleakage is prevent will assure a longer-term success rate of the pulp capping procedure.

\section{MICROBIAL EFFECT}

The mechanism of action of calcium hydroxide on microorganisms can be explained by the influence of $\mathrm{pH}$ on growth, metabolism and bacterial cell division. Estrela et $a l .{ }^{31}$ studied the biological effect of $\mathrm{pH}$ on the enzymatic activity of anaerobic bacteria. The authors believe that the hydroxyl ions from calcium hydroxide develop their mechanism of action in the cytoplasmic membrane, because enzymatic sites are located in the cytoplasmic membrane. This membrane is responsible for essential functions such as metabolism, cellular division and growth and it takes part in the final stages of cellular wall formation, biosynthesis of lipids, transport of electrons and oxidative phosphorylation. Extracellular enzymes act on nutrients, carbohydrates, proteins, and lipids that, through hydrolysis, favor digestion. Intracellular enzymes located in the cell favor respiratory activity of the cellular wall structure. The $\mathrm{pH}$ gradient of the cytoplasmic membrane is altered by the high concentration of hydroxyl ions of calcium hydroxide acting on the proteins of the membrane (proteic denaturation). The effect of the high $\mathrm{pH}$ of calcium hydroxide alters the integrity of the cytoplasmic membrane by means of chemical injury to organic components and transport of nutrients, or by means of the destruction of phospholipids or unsaturated fatty acids of the cytoplasmic membrane, observed in the peroxidation process, which is a saponification reaction ${ }^{30}$.

Adjustment of intracellular $\mathrm{pH}$ is influenced by different cellular processes such as: a) cellular metabolism, b) alterations in shape, mobility, adjustment of transporters and polymerization of cytoskeleton components, c) activation of cellular proliferation and growth, d) conductivity and transport through the membrane, and e) isosmotic cellular volume. Thus, many cellular functions can be affected by $\mathrm{pH}$, including the enzymes that are essential to cellular metabolism $^{101}$.

Lehninger ${ }^{95}$ relates that extreme values of $\mathrm{pH}$ cause the uncoiling of many proteins with loss of their biological activities. For many years the process of denaturation was thought to be irreversible. However, if $\mathrm{pH}$ returns to its normal value, there is a return of native structure of the lost biological activity, that is to say, there is renaturation. Kodukula et al. ${ }^{93}$ also consider that a reactivation of catalytic activity is possible when the enzyme resumes operating in an ideal $\mathrm{pH}$.

Estrela et al. ${ }^{31}$ suggested the hypothesis of an irreversible bacterial enzymatic inactivation under extreme conditions of $\mathrm{pH}$ for a long period of time and also a temporary bacterial enzymatic inactivation with the restoration of normal activity when the $\mathrm{pH}$ returns to the ideal level for enzymatic activity. The irreversible enzymatic inactivation was demonstrated by Estrela et al. ${ }^{27}$ who determined the direct antimicrobial effect of calcium hydroxide on different microorganisms ( $E$. faecalis, $S$. aureus, $P$. aeruginosa and $B$. subtillis). The changes in the cytoplasmic membrane integrity of the microorganisms that favored their destruction occurred after 72 hours (Graphics 4 - 5). Reversible enzymatic inactivation could be observed in another study carried out by Estrela et $a l .{ }^{26}$ who assessed antimicrobial effect of calcium hydroxide

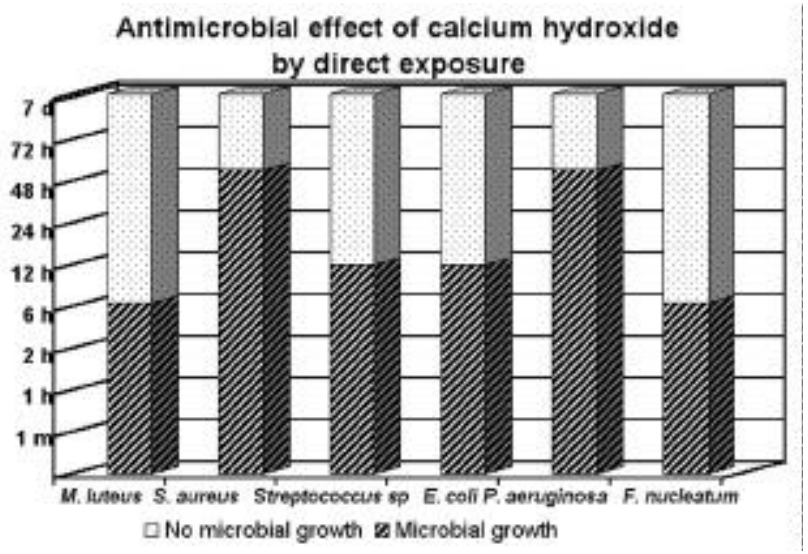

GRAPHIC 4- Antimicrobial effect of calcium hydroxide by direct exposure on various microorganisms ${ }^{27}$

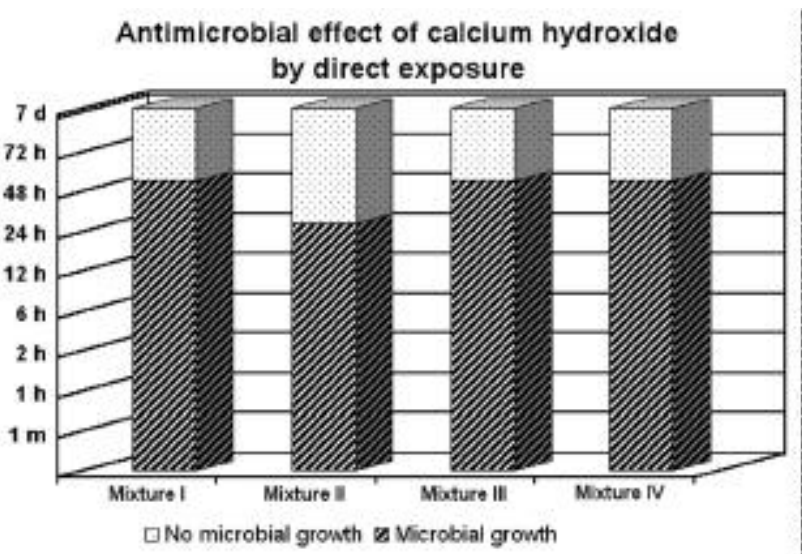

GRAPHIC 5- Antimicrobial effect of calcium hydroxide by direct exposure on various mixtures of microorganisms ${ }^{27}$ 
in infected root canals by the same microorganisms, during periods of 0,48 , and 72 hours and 7 days. Calcium hydroxide was ineffective by distance action during a period of 7 days (Graphic 6).

The neutralization of bacterial toxins is an essential aspect in the selection of an antimicrobial agent. Safavi, Nichols ${ }^{106}$ studied the effect of calcium hydroxide on bacterial lipopolysaccharide (LPS). The calcium hydroxide treatment of LPS was shown to release elevated quantities of hydroxy fatty acids. It was concluded that calcium hydroxide hydrolyzed the lipid moiety of bacterial LPS, resulting in the release of free hydroxy fatty acids. This result suggests that calcium hydroxide-mediated degradation of LPS may be an important reason for the beneficial effects obtained with calcium hydroxide use in clinical endodontics. In another study, Safavi, Nichols ${ }^{107}$ investigated the alteration of biological properties of bacterial lipopolysaccharide by calcium hydroxide treatment. It was concluded that the treatment with calcium hydroxide may alter biological properties of bacterial LPS.

Another aspect to be assessed is the vehicle used for preparing the calcium hydroxide paste. Estrela et al. ${ }^{11}$ determinated the influence of vehicles (saline; camphorated paramonochlorophenol; $1 \%$ chlorhexidine; 3\% sodium lauryl sulphate and Otosporin) on the antimicrobial efficiency of calcium hydroxide. An antimicrobial effect occurred after 48 hours on the cultures of $S$. mutans, $E$. faecalis, S. aureus, $P$. aeruginosa, B. subtilis, C. albicans and the mixture culture, irrespective of the intracanal dressing. Under the conditions of this study, in direct exposure test, the various vehicles associated with calcium hydroxide pastes did not influence the time required for microbial inactivation.

Haenni et $a l .{ }^{37}$ tested the chemical and antimicrobial effects of paste-like suspensions of calcium hydroxide powder with chlorhexidine, sodium hypochlorite or iodine potassium iodine, compared to conventional calcium hydroxide saline paste. The authors observed that calcium hydroxide is a strong alkali, whose $\mathrm{pH}$ is not changed when adding weak acids or alkalis in aqueous suspensions. Under the conditions of this study, mixing calcium hydroxide

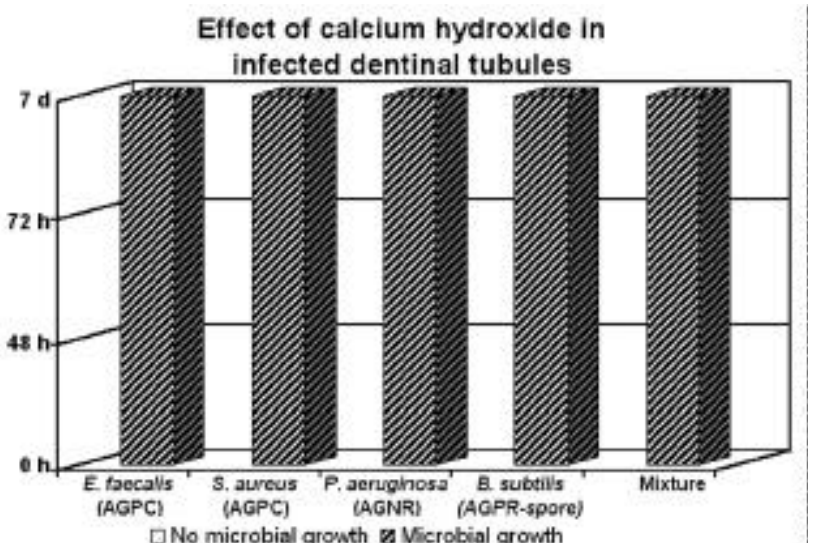

GRAPHIC 6- Antimicrobial effect of calcium hydroxide in infected root canals ${ }^{26}$ powder with the test irrigating solutions did not provide an increased antimicrobial effect compared to a conventional calcium hydroxide saline medication. This results are in accordance with a recently published study by Estrela et $a l .{ }^{11}$, which could not demonstrate an additive antibacterial effect when mixing calcium hydroxide powder with chlorhexidine, but showed that calcium hydroxide does not lose its antibacterial properties in such a mixture.

Safavi, Nakayama ${ }^{105}$ evaluated the influence of mixing vehicle on dissociation of calcium hydroxide in solution. The antimicrobial effects of aqueous preparations of calcium hydroxide have been demonstrated in the past. Calcium hydroxide, when dissolved in water, dissociates into hydroxide and calcium ions. The presence of hydroxide ions in a solution makes it antimicrobial. Recently it was shown that the use of glycerin as a mixing vehicle facilitates placement of calcium hydroxide in the root canals. The influence of nonaqueous mixing vehicles on the dissociation of calcium hydroxide is not clearly understood. In this study the conductivity values for saturated solutions of calcium hydroxide in water was $7,3 \pm 3 \mathrm{mS} / \mathrm{cm}$. The conductivity of calcium hydroxide in pure glycerin or propylene glycol was essentially zero. It was concluded that use of nonaqueous mixing vehicles might impede the effectiveness of calcium hydroxide as root canal dressing.

It's expressive to report the difference between antimicrobial effects in endodontic infections when use calcium hydroxide, camphorated paramonochlorophenol, camphorated phenol. Byström et al. ${ }^{3}$ evaluated the antibacterial effect of camphorated paramonochlorophenol, camphorated phenol and calcium hydroxide in the treatment of infected root canals. After treatment, including intracanal dressing with calcium hydroxide paste, bacteria were recovered from one of 35 treated root canals. After use of camphorated phenol or camphorated paramonochlorophenol as the dressing, bacteria were recovered from 10 of 30 treated root canals. The results indicated that the endodontic treatment of infected root canals could be completed in two appointments when calcium hydroxide paste is used as an intracanal dressing.

The elevated $\mathrm{pH}$ of calcium hydroxide, with values reaching 12.6, is due to the great liberation of hydroxyl ions which are capable of altering the integrity of the bacterial cytoplasmic membrane through the toxic effects generated during the transfer of nutrients or through the destruction of the phospholipids of unsaturated fatty acids. Thus, $\mathrm{pH}$ and surface tension are physical-chemical properties important. The Graphics 7 and 8 show the results of $\mathrm{pH}$ and surface tension of various calcium hydroxide pastes ${ }^{18,22}$.

\section{DISCUSSION}

Researches about induction of tissue repair in dental pulp and antimicrobial effectiveness in endodontic infections have shown calcium hydroxide as the best option ${ }^{3,6-32,40-92}$ (Figures 1 - 3). Two important enzyme properties of calcium hydroxide are the activation of tissue enzymes, such as 
alkaline phosphatase, causing a mineralizing effect and the inhibition of bacterial enzymes causing an antimicrobial effect. Its high $\mathrm{pH}$ inhibits essential enzyme activities: metabolism, growth and cellular division. The influence of $\mathrm{pH}$ alters the integrity of the cytoplasmic membrane by biochemical injury to organic components (proteins, phospholipids) and transport of nutrients ${ }^{30,31}$.

Different substances (distilled water, saline solution, propylene glycol, camphorated paramonochlorophenol, chlorhexidine, glycerin, iodoform, barium sulfate, corticosteroid-antibiotic, antibiotics, anesthetic solution, methylcellulose, detergent) have been associated to calcium hydroxide in an attempt to enhance its properties. When in direct contact with the pulp tissue, calcium hydroxide encourages the deposition of a hard tissue bridge, and the paste can be prepared in a pure form or mixing it with distilled water. A controversial factor when choosing a vehicle is the comparison of the antimicrobial effect of calcium hydroxide in association with hydrosoluble vehicles (distilled water, saline solution) and others vehicles as camphorated paramonochorophenol (CMPC), chlorexidine etc.

The combination of a water-soluble vehicle (such as saline solution) with calcium hydroxide pastes has shown better results when compared to CMPC. Holland et al. ${ }^{69}$

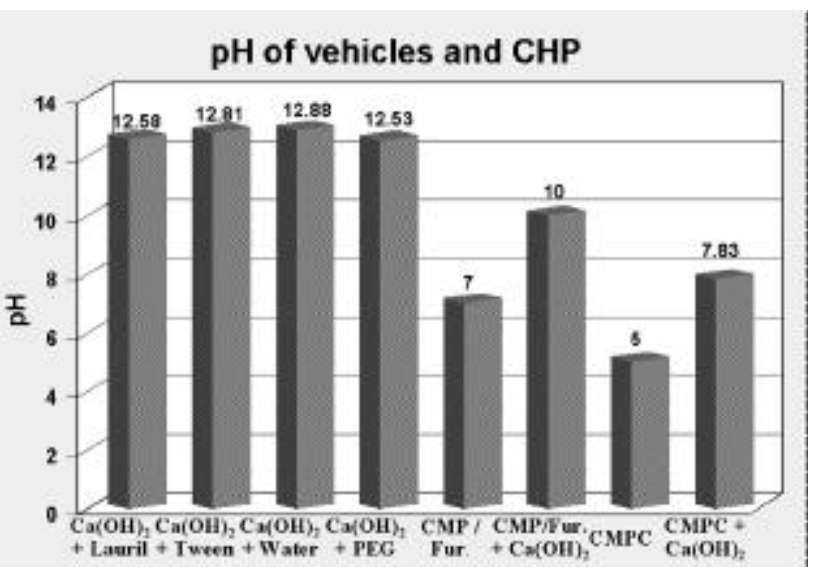

GRAPHIC 7- pH of vehicles and calcium hydroxide pastes ${ }^{22}$

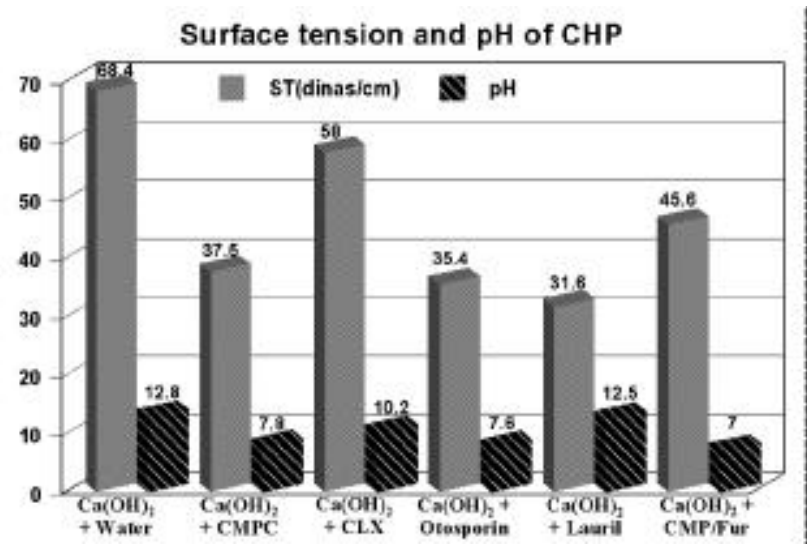

GRAPHIC 8- Surface tension and $\mathrm{pH}$ of calcium hydroxide pastes $^{18}$ evaluated the healing of periapical tissues with different preparations of calcium hydroxide using Calen (polyethylene glycol 400), Calen + CMPC, and calcium hydroxide + anesthetic on dog's teeth. After a 6 month period for the formation of periapical lesion, and another 6 month period

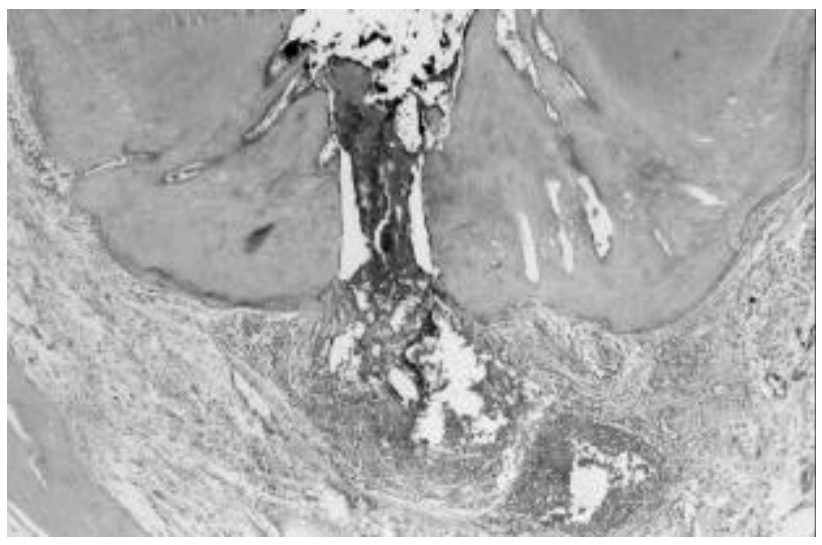

FIGURE 1- Treatment in one visit - Chronic inflammatory reaction in the periodontal ligament (H.E. X100) (Holland et al. ${ }^{62}$.

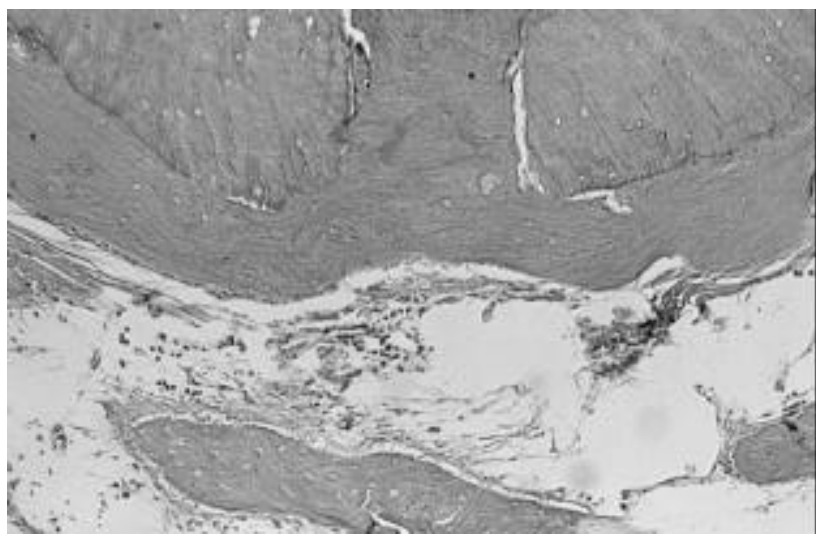

FIGURE 2- Calcium hydroxide 7 days. Complete closure of the main root canal by neoformed cementum (H.E. X100) (Holland et al. ${ }^{62}$ ).

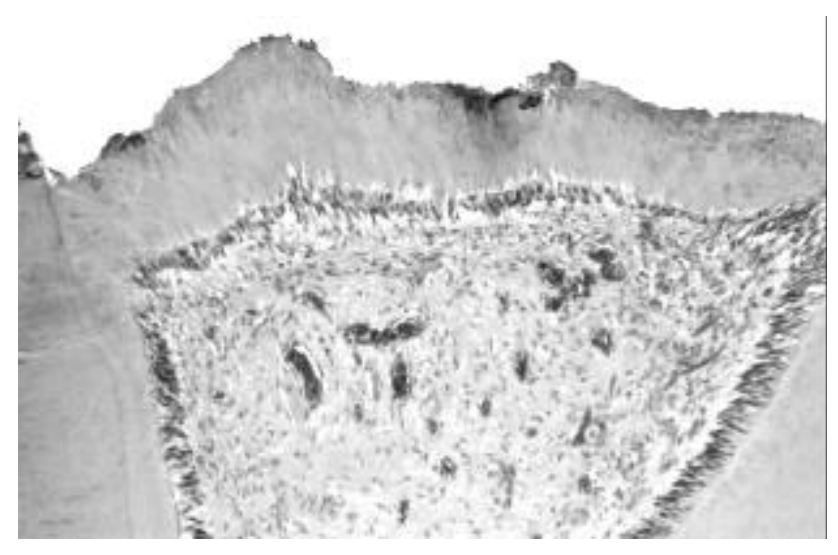

FIGURE 3- Calcium hydroxide - Complete hard tissue bridge on dental pulp (H.E. X40) (Holland et al. ${ }^{68}$ ). 
for the histopathological evaluation following treatment, the results showed that the association between CMPC and Calen did no improve treatment results, and that the average total repair for the three groups was $50 \%$. In another study, Holland et al..$^{44}$ studied the healing process in 60 teeth roots with periapical lesion using calcium hydroxide in combination with saline solution, calcium hydroxide in combination with CMPC, CMPC combined with furacin, and CMPC alone. The results were better with the use of calcium hydroxide associated with saline solution (approximately $60 \%$ of total repair and $40 \%$ of partial repair). In the case of calcium hydroxide associated with CMPC, results showed $20 \%$ of total repair, $70 \%$ of partial repair, and $10 \%$ of unsuccessful repair. Treatment carried out in a single session showed $40 \%$ of unsuccessful repair, $40 \%$ of partial repair, and only $20 \%$ of repair.

The need of considering the study model is essential, as the results of some tests must be carefully assessed. Estrela et al. ${ }^{13}$ studied two methods for determining the antimicrobial effectiveness of calcium hydroxide plus saline, polyethylene glycol or camphorated paramonochlorophenol, by direct exposure test (DET) and agar diffusion test (ADT) on various biological indicators. The data obtained showed that both DET and ADT are useful in establishing the calcium hydroxide antimicrobial spectrum, thus, improving infection control protocols. The direct exposure method is independent of other variables and is a practical laboratory procedure. The complete antimicrobial effect was observed after $48 \mathrm{~h}$ on indicator microorganisms, in both tests, irrespective of the calcium hydroxide paste vehicle. Estrela et $a l .{ }^{11}$ verified the antimicrobial potential of calcium hydroxide pastes with different vehicles over periods of 1 min, $48 \mathrm{~h}, 72 \mathrm{~h}$ and 7 days. The antimicrobial action was not influenced by any of the vehicles what suggests that they have a supportive role in the process by providing appropriate conditions for dissociation and diffusion as well as enhancing complete filling of the root canal; these are important factors for antimicrobial potential and tissue healing capability.

Another interesting study has also shown the superiority of calcium hydroxide in promoting LPS hydrolysis. Buck et $a l .^{2}$ evaluated the detoxification of endotoxin by endodontic irrigants (chlorhexidine, sodium hypochlorite, chlorhexidine chloride, ethanol, EDTA, water) and calcium hydroxide. The results showed that the biologically active portion of endotoxin, lipid A, is hydrolyzed by highly alkaline chemicals, namely calcium hydroxide or the mixture of chlorhexidine, sodium hypochlorite and ethanol. EDTA, sodium hypochlorite, chlorhexidine, chlorhexidine chloride, ethanol and water (control) showed little or no detoxifying ability in lipid A.

Safavi, Nakayama ${ }^{105}$ showed that the influence of nonaqueous mixing vehicles on the dissociation of calcium hydroxide is not clearly under study. Their study the conductivity of calcium hydroxide in pure Glycerin or Propylene Glycol is essentially zero. It was concluded that use nonaqueous mixing vehicles may impede the effectiveness of calcium hydroxide as root canal dressing.
In the search for explaining the antimicrobial mechanism of calcium hydroxide, it was observed that the enzymes in the cytoplasmic membrane were the targets of $\mathrm{pH}$ changes, which can lead to a reversible or irreversible inactivation of aerobic, anaerobic, Gram-positive and Gram-negative microorganisms. Obviously, the antimicrobial effect depends on the rate of release of hydroxyl ions, its availability, time of contact for direct or indirect action (diffusibility of hydroxyl ions within dentinal tubules) in order to show its real effectiveness. Thus, the reasoning should follow another direction. With the aim to choose the intracanal dressing to be used it is necessary to consider the microbiota of the infected root canal, the host response, and the mechanism of action of the medication. Nevertheless, it is necessary for the medication to have enough time for being effective, able to act at a distance and for neutralizing the residue of aggressor agents.

However, significant numbers of professionals are favorable to one-visit root canal treatment in endodontic infections cases. Holland et al. ${ }^{61}$ observed the healing process in dog's teeth with apical periodontitis after root canal treatment in one or two appointments. Dog's premolars and anterior teeth had their root canals opened to the oral environment for 6 months before being treated. After root canal treatment they were filled by the lateral condensation technique with gutta-percha points and Sealapex in one appointment or after dressing with calcium hydroxide for 7 and 14 days. Six months following the treatment the animals were sacrificed_and the tissues prepared for histomorphological analysis. Scores attributed to the different histomorphological events were submitted to statistical analysis, which resulted in ranking the experimental groups from the best to the worst in the following way: a) calcium hydroxide 14 days; b) calcium hydroxide 7 days; c) one appointment. The use of calcium hydroxide as intracanal medicaments between appointments helps to achieve better results in the treatment that in one appointment.

It is necessary, whenever possible, to allow time for calcium hydroxide paste to manifest its potential action on the microorganisms present in endodontic infections. The maintenance of a high concentration of hydroxyl ions can change enzymatic activity and promote its inactivation. The elimination of microorganisms by calcium hydroxide paste in infected root canal in vitro occurred in 60 days when saline solution was chosen as endodontic irrigant to avoid masking the antimicrobial potential of calcium hydroxide paste ${ }^{16}$. However, the endodontic irrigant can influence the microbial control positively ${ }^{14}$. Sydney ${ }^{117}$ verified endodontic microbiota at different times after root canal preparation in teeth with asymptomatic apical periodontitis and after the use of calcium hydroxide paste as intracanal dressing. The endodontic microbiota was reduced to $77.8 \%$ after 1 week, and $E$. faecalis was isolated in only one instance after 6 weeks.

The resistance of some bacterial species is essential in the sanitization process. According to that, Love ${ }^{96}$ evaluated a possible mechanism that would explain how E. faecalis 
could survive and grow within dentinal tubules and reinfect an obturated root canal. It is postulated that a virulence factor of $E$. faecalis in failed endodontically treated teeth may be related to the ability of $E$. faecalis cells to maintain the capability to invade dentinal tubules and adhere to collagen in the presence of human serum. Evans et al. ${ }^{33}$ studied the mechanisms involved in the resistance of Enterococcus faecalis to calcium hydroxide. The $E$. faecalis was resistant to calcium hydroxide at a $\mathrm{pH}$ of 11.1 but not $\mathrm{pH} 11.5$. No difference in cell survival was observed when protein synthesis was blocked during stress induction, however, addition of a proton pump inhibitor resulted in a dramatic reduction of cell viability of $E$. faecalis in calcium hydroxide. Survival of E. faecalis in calcium hydroxide appears to be unrelated to stress induced by protein synthesis, but functioning proton pump is critical for the survival of $E$. faecalis at high $\mathrm{pH}$.

The importance of the calcium hydroxide in endodontic developed occurred due to specially its biological properties, that should not be neglected. Scientific investigations should be carried out frequently every in order to evaluate materials recommended for use in endodontic. Nevertheless, we should always remember the difference between scientific fact and scientific opinion. Scientific fact originates from an investigation with specific parameters and methodologies, reproducible and well oriented with the aim to study a new material, a new technique or to analyze a questionable fact. Sometimes to establish a quality control. On the other hand, the "scientific" opinion, in several cases, originates from personal opinions, with no scientific criteria, most of the time speculative and sensationalist. Thus, the scientific fact motivated this study about calcium hydroxide, based in scientific evidences.

\section{CONCLUSIONS}

Under the conditions of this retrospective of literature, it is possible to state that:

1. Dentin is considered the best pulpal protective, and calcium hydroxide has proved, through numerous studies, its capability of inducing the formation of a mineralized bridge over pulpal tissue.

2. It is necessary, whenever possible, to give time for calcium hydroxide paste to manifests its potential of action on the microorganisms present in endodontic infections. The maintenance of a high concentration of hydroxyl ions can change bacteria enzymatic activity and promote its inactivation.

3. The site of action of hydroxyl ions of calcium hydroxide includes the enzymes in the cytoplasmic membrane. This medication has a large scope of action, and therefore is effective on a wide range of microorganisms, regardless their metabolic capability. In microbial world, cytoplasmic membranes are similar, irrespective from microorganisms morphological, tinctorial and respiratory characteristics, which means that this medication has a similar effect on aerobic, anaerobic, Gram-positive and
Gram-negative bacteria.

4. Calcium hydroxide as temporary dressing used between appointments promotes better results on the periapical healing process than the treatment in one appointment.

\section{RESUMO}

Estrela C, Holland R. Hidróxido de cálcio: estudo baseado em evidências científicas. J Applied Oral Science 2003;

As características do hidróxido de cálcio se desenvolvem a partir da dissociação em íons cálcio e hidroxila. A ação desses íons nos tecidos e bactérias explica as características biológicas e antimicrobianas dessa substância. Por meio desta retrospectiva da literatura, baseada em evidências científicas, é possível afirmar que: 1. A dentina é considerada a melhor proteção pulpar, e o hidróxido de cálcio provou, através de numerosos estudos, sua capacidade de induzir a formação de barreira mineralizada sobre o tecido pulpar. 2. É necessário, sempre que possível, dar tempo à pasta de hidróxido de cálcio para manifestar seu potencial de ação sobre os microrganismos presentes nas infecções endodônticas. A manutenção de alta concentração de íons hidroxila pode alterar a atividade enzimática bacteriana e promover sua inativação. 3. O sítio de ação dos íons hidroxila e cálcio incluem as enzimas presentes na membrana citoplasmática. Esta medicação tem um largo espectro de ação, independentemente da capacidade metabólica dos microrganismos. As membranas citoplasmáticas são similares, independentemente das características morfológicas, tintoriais e respiratórias dos microrganismos, o que significa que essa medicação atua de forma similar sobre bactérias aeróbias, anaeróbias, Grampositivas e Gram-negativas. 4. O hidróxido de cálcio como medicação intracanal, entre sessões, promove melhores resultados no processo de reparação periapical do que o tratamento em sessão única.

UNITERMOS: Hidróxido de cálcio; Polpa dentária; Medicação intracanal; Mineral trioxide agregate; Cimento Portland.

\section{REFERENCES}

1- Binnie WH, Rowe AHR. A histological study of the periapical tissues of incompletely formed pulpless teeth filled with calcium hydroxide. J Dent Res 1973; 52:1110-16.

2- Buck RA, Cai J, Eleazer PD, Staat RH, Hurst HE. Detoxification of endotoxin by endodontic irrigants and calcium hydroxide. J Endod 2000; 27:325-327.

3- Byström A, Claesson R, Sundqvist G. The antibacterial effect of camphorated paramonochlorophenol, comphorated phenol and calcium hydroxide in the treatment of infected root canals. Endod Dent Traumatol 1985; 1:170-75. 
4- Costa CAS, Giro EMA, Nascimento ABL, Teixeira HM, Hebling J. Short-term evaluation of the pulpo-dentin complex response to a resin-modified glass-ionomer cement and a bonding agent applied in deep cavities. Dent Materials 2003; 19:739-46.

5- Eda S. Histochemical analysis on the mechanism of dentin formation in dog's pulp. Bull Tokyo Dent Coll 1961; 2:59-88.

6- Estrela C. Análise química de pastas de hidróxido de cálcio, frente à liberação de íons de cálcio, de íons hidroxila e ação do carbonato de cálcio na presença de tecido conjuntivo de cão. (Tese de Doutorado em Endodontia). São Paulo: Faculdade de Odontologia da Universidade de São Paulo - USP; 1994.

7- Estrela C. Eficácia antimicrobiana de pastas de hidróxido de cálcio. (Tese de Livre-Docência). Ribeirão Preto: Faculdade de Odontologia da Universidade de São Paulo - USP; 1997.

8- Estrela C, Bammann LL. Efeito enzimático do hidróxido de cálcio. Rev Ass Bras Odontol Nac 1999; 7:32-42.

9- Estrela C, Bammann LL, Estrela CRA, Silva RS, Pécora JD. Antmicrobial and chemical study of MTA, Portland cement, calcium hydroxide paste, Sealapex and Dycal. Braz Dent J 2000; 11:3-9.

10- Estrela C, Bammann LL, Lopes HP, Moura J. Análise comparativa da ação antibacteriana de três cimentos obturadores contendo hidróxido de cálcio. Rev Ass Bras Odontol Nac 1995; $3: 185-87$

11- Estrela C, Bammann LL, Pimenta FC, Pécora JD. Control of microorganism in vitro by calcium hydroxide pastes. Int Endod $\mathrm{J}$ $2001 ; 34: 416-18$

12- Estrela C, Bammann LL, Sydney GB, Moura J. Efeito antibacteriano de pastas de hidróxido de cálcio sobre bactérias aeróbias facultativas. Rev Fac Odontol Bauru 1995; 3:109-14.

13- Estrela C, Estrela CRA, Bammann LL, Pécora JD. Two methods to evaluate the antimicrobial action of calcium hydroxide paste. J Endod 2001; 27:720-23.

14- Estrela C, Estrela CRA, Barbin EL, Spanó JCE, Marchesan MA, Pécora JD. Mechanism of action of sodium hypochlorite. Braz Dent J 2002; 13:113-17.

15- Estrela C, Estrela CRA, Hollanda ACB, Decurcio DA, Pécora JD. Iodoform effect on antimicrobial potential of intracanal medicament. Braz Endod J 2002; 6:11-17.

16- Estrela C, Estrela CRA, Pécora JD. A study of the time necessary for calcium hydroxide to eliminate microorganism in infected canals. J Applied Oral Science 2003; 12:133-137.

17- Estrela C, Estrela CRA, Silva RS, Pécora JD. Molar conductivity of calcium hydroxide solutions. Braz Endod J 2001; 5:13-17.

18- Estrela C, Estrela CRA, Silva RS, Pécora JD. Surface tension of calcium hydroxide associated at different substances. Braz Endod J 2002; 6:23-25.
19- Estrela C, Lopes HP, Felippe-Jr O, Sydney GB. Chemical analysis of calcium carbonate present in various calcium hydroxide samples. Braz Endod J 1997; 2:7-9.

20- Estrela C, Mamede-Neto I, Estrela CRA, Pécora JD. Evaluation of density of calcium hydroxide pastes in dog's mandible. Braz Endod J 1998; 3:24-30.

21- Estrela C, Mamede-Neto I, Lopes HP, Estrela CRA, Pécora JD. Root canal filling with calcium hydroxide using different techniques. Braz Dent J 2002; 13:53-56.

22- Estrela C, Pécora JD, Silva RS. pH analyse of vehicles and calcium hydroxide pastes. Braz Endod J 1998; 3:41-47.

23- Estrela C, Pécora JD, Sousa-Neto MD, Estrela CRA, Bammann LL. Effect of vehicle on antimicrobial properties of calcium hydroxide paste. Braz Dent J 1999; 10:63-72.

24- Estrela C, Pesce HF. Chemical analysis of the liberation of calcium and hydroxyl ions of calcium hydroxide pastes in the presence of connective tissue of the dog. Part I. Braz Dent J 1996; 7:41-46.

25- Estrela C, Pesce HF. Chemical analysis of the formation of calcium carbonate and its influence on calcium hydroxide pastes in the presence of connective tissue of the dog. Part II. Braz Dent J 1997; 8:49-53

26- Estrela C, Pimenta FC, Ito IY, Bammann LL. Antimicrobial evaluation of calcium hydroxide in infected dentinal tubules. $\mathbf{J}$ Endod 1999; 26:416-18.

27- Estrela C, Pimenta FC, Ito IY, Bammann LL. In vitro determination of direct antimicrobial effect of calcium hydroxide. J Endod 1998; 24:15-17.

28- Estrela C, Ribeiro RG, Estrela CRA, Pécora JD, Souza-Neto MD. Antmicrobial effect of $2 \%$ sodium hypochlorite and $2 \%$ chlorhexidine tested by different methods. Braz Dent J 2003; 14:58-62.

29- Estrela C, Sydney GB. EDTA effect on root dentin pH after exchange of calcium hydroxide paste. Braz Endod J 1997; 2:2023 .

30- Estrela C, Sydney GB, Bammann LL, Felippe-Jr O. Mechanism of the action of calcium and hydroxyl ions of calcium hydroxide on tissue and bacteria. Braz Dent J 1995; 6:85-90.

31- Estrela C, Sydney GB, Bammann LL, Fellipe-Jr O. Estudo do efeito biológico do $\mathrm{pH}$ na atividade enzimática de bactérias anaeróbias. Rev Fac Odontol Bauru 1994; 2:31-38.

32- Estrela C, Sydney GB, Pesce HF, Felippe-Jr O. Dentinal diffusion of hydroxil ions of various calcium hydroxide pastes. Braz Dent J 1995; 6:5-9.

33- Evans M, Davies JK, Sundqvist G, Fidgor D. Mechanism involved in the resistance of Enterococcus faecalis to calcium hydroxide. Int Endod J 2002; 35:221-28.

34- Glass RL, Zander HA. Pulp healing. J Dent Res 1949; 28:97107. 
35- Gomes BPFA, Ferraz CCR, Vianna ME, Rosalen PL, Zaia AA, Teixeira FB, Souza-Filho FJ. In Vitro antimicrobial activity of calcium hydroxide pastes and their vehicles against selected microorganisms. Braz Dent J 2002; 13:155-161.

36- Greenwood NN, Earnshaw A. Cheminsty of the elements. New York: Pergamon Press; 1984. p.117-54.

37- Haenni S, Schmidlin PR, Mueller B, Sener B, Zehnder M. Chemical and antimicrobial properties of calcium hydroxide mixed with irrigants solutions. Int Endod J 2003; 36:100-05.

38- Hermann BW. Calciumhydroxyd als mittel zurn behandel und füllen vonxahnwurzelkanälen. [Thesis] Würzburg; 1920. 50p.

39- Heitersay GS. Calcium hydroxide in the treatment of pulpless teeth with associated pathology. J Brith Endod Soc 1975; 8:7493.

40- Holland R. Processo de reparo da polpa dental após pulpotomia e proteção com hidróxido de cálcio. (Tese de Doutorado). Araçatuba: Faculdade de odontologia, Universidade Estadual Paulista; 1966.

41- Holland R. Processo de reparo do coto pulpar e dos tecidos periapicais após biopulpectomias e obturação de canal com hidróxido de cálcio ou óxido de zinco e eugenol. Estudos histológicos em dentes de cães. (Tese de Livre-Docência) Araçatuba: Faculdade de Odontologia de Araçatuba - Universidade Estadual Paulista; 1975.

42- Holland R. Emprego tópico de medicamentos no interior de canais radiculares. Odonto Máster - Endodontia 1994; 1:1-13.

43- Holland R. Histochemical response of amputed pulps to calcium hydroxide. Rev Bras Pesq Med e Biol 1971; 4:83-95.

44- Holland R, Cruz AG, Nery MJ, Souza V, Otoboni-Filho JA, Bernabé PFE. Efecto de los medicamentos colocados en el interior del conducto, hidrosolubles y no hidrosolubles en el proceso de reparación de dientes de perro con lesión periapical. Endodoncia 1999; 17:90-100.

45- Holland R, Cruz AG, Souza V, Nery MJ, Bernabé PFE, Otoboni-Filho JA. Recambio del hidróxido de calcio después de la pulpotomia y su influencia en la reparación. Estudio histológico en dientes de monos. Endodoncia 1999; 17:35-45.

46- Holland R, Delgado RJM, Souza V. Defeitos em forma de tunel em pontes de dentina são características exclusivas do emprego do hidróxido de cálcio? Rev Ciência Odontol 2001; 4:51-6.

47- Holland R, Ingle JI, Valle GF, Taintor JF. Influence of bony resorption on Endodontic treatment. O Surg O Med O Pathol $1983 ; 55: 191-203$.

48- Holland R, Maisto OA, Souza V, Maresca BM, Nery MJ Acción y velocidad de reabsorción de didtintos materiales de obturación de conductos radiculares em el tejido periapical. Rev Assoc Argentina 1981; 69:7-17.
49- Holland R, Mello W, Nery MJ, Souza V, Bernabé PFE, Otoboni-Filho JA. Healing process of Dog's dental pulp after pulpotomy and pulp covering with calcium hydroxide in powder or paste form. Acta Odontol Pediatr 1981; 2:47-51.

50- Holland R, Mello W, Nery MJ, Souza V, Bernabé PFE, Otoboni-Filho JA. The influence of the sealing material in the healing process of inflamed pulps capped with calcium hydroxide or zinc oxide-eugenol cement. Acta Odontol Pediatr 1981; 2:5-9.

51- Holland R, Mello W, Souza V, Nery MJ, Bernabé PFE, Otoboni-Filho JA. Reacción de la pulpa y tejidos periapicales de dientes de perros, com forámenes incompletamente formados, posteriormente a la pulpotomia y protección com hidróxido de cálcio o formocresol: estudo histologico a distância. Endodoncia $1983 ; 1: 33-38$.

52- Holland R, Murata SS, Souza V, Lopes HP, Salia O. Análise do selamento marginal obtido com cimentos à base de hidróxido de cálcio. Rev Ass Paul Cir Dent 1996; 50:61-64.

53- Holland R, Nery MJ, Mello W, Souza V, Bernabé PFE, Otoboni-Filho JA. Root canal treatment with calcium hidroxide I - Effect of overfilling and refilling. O Surg O Med O Pathol 1979; 47:87-92.

54- Holland R, Nery MJ, Mello W, Souza V, Bernabé PFE, Otoboni-Filho JA. Root canal treatment with calcium hydroxide II - Effect of instrumentation beyond the apices. O Surg O Med O Pathol 1979; 47:93-96.

55- Holland R, Nery MJ, Mello W, Souza V, Bernabé PFE, Otoboni-Filho JA. Root canal treatment with calcium hydroxide III - Effect of debris and pressure filling. O Surg O Med O Pathol 1979; 47:185-88.

56- Holland R, Nery MJ, Souza V, Mello W, Bernabé PFE, Otoboni-Filho JA. The effect of corticosteroid-antibiotic dressing in the behaviour of the periapical tissue of dog's teeth after instrumentation. Rev Odontol UNESP 1981; 10:21-25.

57- Holland R, Nery MJ, Souza V, Mello W, Bernabé PFE, Otoboni-Filho JA. The effect of the filling material in the tissue reactions following a prool plugging of the root canal with dentin chips. A histologic study in monkey's teeth. O Surg O Med O Pathol 1983; 53:398-401.

58- Holland R, Otoboni-Filho JA, Bernabé PFE, Nery MJ, Souza $\mathrm{V}$, Berbert A. Effect of root canal status on periodontal healing after surgical injury in dogs. Endod Dent Traumatol 1994; 10:7782.

59- Holland R, Otoboni-Filho JA, Souza V, Mello W, Nery MJ, Bernabé PFE, Dezan-Jr E. Calcium hydroxide and corticosteroidantibiotic association as dressings in cases of biopulpectomy. A comparative study in dogs teeth. Braz Dent J 1998; 9:67-76.

60- Holland R, Otoboni-Filho JA, Souza V, Nery MJ, Bernabé PFE, Dezan-Jr E. Reparação dos tecidos periapicais com diferentes formulações de $\mathrm{Ca}(\mathrm{OH})_{2}$ - Estudo em cães. Rev Ass Paul Cir Dent $1999 ; 53: 327-31$ 
61- Holland R, Otoboni-Filho JA, Souza V, Nery MJ, Bernabé PFE, Dezan-Jr E. A comparison of one versus two appointment endodontic therapy in dogs' teeth with apical periodontitis. J Endod 2003; 29:121-25.

62- Holland R, Otoboni-Filho JA, Souza V, Nery MJ, Bernabé PFE, Dezan-Jr E.Tratamiento endodôntico en una o en dos visitas. Estudio histológico en dientes de perros con lesión periapical. Endodoncia 2003; 21:20-27.

63- Holland R, Pinheiro CE, Mello W, Nery MJ, Souza V. Histochemical analysis of the dog's dental pulp after pulp capping with calcium, barium and strontium hydroxides. J Endod 1982; $8: 444-47$

64- Holland R, Soares IJ, Soares IM. Influence of irrigation and intracanal dressing on the healing process of dog's teeth with apical periodontitis. Endod Dent Traumatol 1992; 8:223-29.

65- Holland R, Soares IJ, Soares TML, Dias NV. The effect of the dressing in the tissue reactions following apical plugging of the root canal of dogs' pulpless teeth with chips. Rev Odontol UNESP 1989; 18:101-08.

66- Holland R, Souza V. Ability of a new calcium hydroxide root canal filling material to induce hard tissue formation. J Endod $1985 ; 11: 535-43$

67- Holland R, Souza V, Mello W, Nery MJ, Bernabé PFE, Otoboni-Filho JA. Permeability of the hard tissue bridge formed after pulpotomy with calcium hydroxide: a histologic study. J Amer Dent Ass 1979: 99:472-75.

68- Holland R, Souza V, Mello W, Nery MJ, Bernabé PFE, Otoboni-Filho JA. Healing process of dog's dental pulp after pulpotomy and protection with calcium hydroxide or Dycal. Rev Odontol Unesp 1979; 8:67-73.

69- Holland R, Souza V, Mello W, Russo MC. Healing process of the pulp stump and periapical tissues in dog teeth. II. Histological findings following root filling with zinc oxide-eugenol. Rev Fac Odontol Araçatuba 1977; 6:59-67.

70- Holland R, Souza V, Mello W, Russo MC. Healing process of the pulp stump and periapical tissue in dog teeth. III Histopathological findings following root filling with calcium hydroxide. Rev Fac Odontol Araçatuba 1978; 7:25-30.

71- Holland R, Souza V, Milanezi LA. Behaviour of pulp stump and periapical tissues to some drugs used a root canal dressings. A morphological study. Rev Bras Pesq Med Biol 1969; 2:13-23.

72- Holland R, Souza V, Milanezi LA. Estudo morfológico do coto pulpar e tecidos periapicais frente à alguns materiais empregados nas obturações dos canais radiculares. Ciência e Cultura 1968; 20:355.

73- Holland R, Souza V, Murata SS. Técnica da pulpotomia com troca de hidróxido de cálcio. Rev Ciência Odontol 1999; 2:7-12.

74- Holland R, Souza V, Murata SS, Nery MJ, Bernabé PFE, Otoboni-Filho JA, Dezan-Jr E. Healing process of dog dental pulp after pulpotomy and pulp covering with mineral trioxide aggregate or portland cement. Braz Dent J 2001; 12:109-13.
75- Holland R, Souza V, Nery MJ, Bernabé PFE, Mello W, Otoboni-Filho JA. The effect of calcium hydroxide in dentine. Rev Fac Odontol Araçatuba 1978; 7:177-80.

76- Holland R, Souza V, Nery MJ, Bernabé PFE, Otoboni-Filho JA, Dezan-Jr E. Agregado de trióxido mineral y cemento Portland en la obturación de conductos radiculares de perro. Endodoncia 2001; 19:275-80

77- Holland R, Souza V, Nery MJ, Bernabé PFE, Otoboni-Filho JA, Dezan-Jr E, Murata SS. Calcium salts deposition in rat connective tissue after the implantation of calcium hydroxide contaming sealers. J Endod 1979; 28:173-76.

78- Holland R, Souza V, Nery MJ, Faraco-Jr IM, Bernabé PFE, Otoboni-Filho JA, Dezan-Jr E. Reaction of Rat Connective Tissue to Implanted Dentin Tube Filled with Mineral Trioxide Aggregate, Portland Cement or Calcium Hydroxide. Braz Dent J 2001; 12:38.

79- Holland R, Souza V, Nery MJ, Faraco-Jr IM, Bernabé PFE, Otoboni-Filho JA, Dezan-Jr E. Reaction of rat connective tissue to implanted dentin tubes filled with a white mineral trioxide aggregate. Braz Dent J 2002; 13:23-26.

80- Holland R, Souza V, Nery MJ, Mello, W. Resposta ao tecido conjuntivo subcutâneo do rato ao implante de alguns materiais obturadores de canal. Rev Fac Odontol Araçatuba 1973; 2:21725.

81- Holland R, Souza V, Nery MJ, Mello, W, Bernabé PFE. Root canal treatment with calcium hydroxide. Effect of an oil water soluble vehicle. Rev Odontol Unesp 1983; 12:1-6.

82- Holland R, Souza V, Nery MJ, Mello W, Bernabé PFE, Otoboni-Filho JA. Comportamento dos tecidos periapicais de dentes de cães com rizogênese incompleta após obturação dos canais radiculares com diferentes materiais obturadores. Rev Bras Odontol 1992; 49:49-53.

83- Holland R, Souza V, Nery MJ, Mello W, Bernabé PFE, Otoboni-Filho JA. Effect of the dressing in root canal treatment with calcium hydroxide. Rev Fac Odontol Araçatuba 1978; 7:3945 .

84- Holland R, Souza V, Nery MJ, Mello W, Bernabé PFE, Otoboni-Filho JA. Root canal treatment of pulpless teeth with calvital or zinc oxide-eugenol, in one or two sittings. Histological study in dog. Rev Fac Odontol Araçatuba 1978; 7:47-53.

85- Holland R, Souza V, Nery MJ, Mello W, Bernabé PFE, Otoboni-Filho JA. A histological study of the effect of calcium hydroxide in the treatment of pulpless teeth of dogs. J Brit Endod Soc 1979; 12:15-23.

86- Holland R, Souza V, Nery MJ, Mello W, Bernabé PFE, Otoboni-Filho JA. Effect of the dressing in root canal treatment with calcium hydroxide. Rev Fac Odontol Araçatuba 1980; 7:3945

87- Holland R, Souza V, Nery MJ, Mello W, Bernabé PFE, Otoboni-Filho JA. Tissues reactions following apical plugging of the root canal with infected dentin chips. O Surg O Med O Pathol 1980; 49:366-69. 
88- Holland R, Souza V, Nery MJ, Otoboni Filho JA, Bernabé PFE, Dezan-Jr E. Reaction of rat connective tissue to implanted dentin tubes filled with mineral trioxide aggregate or calcium hydroxide. J Endod 1999; 25:161-66.

89- Holland R, Souza V, Nery MJ, Otoboni Filho JA, Bernabé PFE, Dezan-Jr E. Reaction of dogs' teeth to root canal filling with mineral trioxide aggregate or a glass ionomer sealer. J Endod 1999; $25: 728-30$

90- Holland R, Souza V, Otoboni-Filho JA. Root canal treatment with calcium hydroxide. I - Effect of overfilling and refilling. O Surg O Med O Pathol 1979; 47:87-92.

91- Holland R, Souza V, Otoboni-Filho JA. Root canal treatment with calcium hydroxide. II - Effect of instrumentation beyond the apices. O Surg O Med O Pathol 1979; 47:93-96.

92- Holland R, Souza V, Tagliavini RL, Milanezi LA. Healing process of teeth with open apices: histological study. Bull Tokyo Dent Coll 1971; 12:333-38.

93- Kodukula PS, Prakasam TBS, Anthonisen AC. Role of $\mathrm{pH}$ in biological wastewater treatment process. In: Bazin MJ, Prosser JI. Physiological models in microbiology. Florida: CRC Press; 1988. p.113-34.

94- Lee SJ, Monsef M, Torabinejad M. Sealing ability of a mineral trioxide aggregate for repair of lateral root perforations. J Endod $1993 ; 19: 541-44$

95- Lehninger AL. Princípios de bioquímica. 2.ed. São Paulo: Sarvier; 1986.

96- Love RM. Enterococcus faecalis - mechanism for its role in endodontic failure. Int Endod J 2001; 34:399-406.

97- Markowitz K, Moynihan M, Liu M, Kim S. Biologic properties of eugenol and zinc oxide-eugenol. O Surg O Med O Pathol 1992; 73:729-37.

98- Mello W, Holland R, Souza V. Capeamento pulpar com hidróxido de cálcio ou pasta de óxido de zinco e eugenol. Rev Fac Odontol Araçatuba 1972; 1:33-44.

99- Pitt Ford TR, Torabinejad M, Abedi HR, Bakland LK, Kariyawasan SP. Using mineral trioxide aggregate as a pulpcapping material. J Am Dent Assoc 1996; 127:1491-96.

100- Pitt Ford TR, Torabinejad M, McKendry DJ, Hong CU, Kariyawasan SP. Use of mineral trioxide aggregate for repair of furcal perforations. O Surg O Med O Pathol 1995; 79:756-62.

101- Putnam RW. Intracellular $\mathrm{pH}$ regulation. In: Cell physiology. San Diego: Academic Press; 1995. p.212-29.

102- Russo M, Souza V, Holland R. Effects of the dressing with calcium hydroxide under pressure on the pulpal healing of pulpotomized human teeth. Rev Fac Odontol Araçatuba 1974; 3:303-306.

103- Rutherford RB et al. Induction of reparative dentine formation in monkeys by recombinant human osteogenic protein-1. Archs Oral Biol 1993; 38:571-576.
104- Rutherford RB, Spangberg L, Tucker M, Charette M. Transdentinal stimulation of reparative dentine formation by osteogenic protein-1 in monkeys. Arch Oral Biol 1995; 40:68183.

105- Safavi KE, Nakayama TA. Influence of mixing vehicle on dissociation of calcium hydroxide in solution. J Endod 2000; 26:649-51

106- Safavi KE, Nichols FC. Effect of calcium hydroxide on bacterial lipopolysaccharide. J Endod 1993; 19:76-78.

107- Safavi KE, Nichols FC. Alteration of biological properties of bacterial lipopolysaccharide by calcium hydroxide treatment. J Endod 1994; 20:127-129.

108- Saidon J, He J, Zhu Q, Safavi K, Spangberg LSW. Cell and tissue reactions to mineral trioxide aggregate and Portland cement. O Surg O Med O Pathol 2003; 95:483-89.

109- Seux D, Couble ML, Hartman DJ, Gauthier JP, Magloire H. Odontoblast like cytodifferentation of human pulp cells in vitro in the presence of a calcium hydroxide contamining cement. Archs Oral Biol 1991; 36:117-28.

110- Siqueira-Jr JF, Uzeda M. Influence of different vehicles on the antimicrobial effects of calcium hydroxide. J Endod 1998; 24:63-5.

111- Smith AJ, Cassidy N, Perry H, Begue-Kirn C, Ruch JV, Lesot H. Reactionary dentinogenesis. Int J Developm Biol 1995; 39:273280.

112- Smith AJ, Tobias RS, Cassidy N, Plant GC, Begue-Kirn C, Ruch JV, Lesot H. Odontoblast stimulation in ferrets by dentine matrix components. Arch Oral Biol 1994; 39:13-22.

113- Soares IML. Resposta pulpar ao MTA - agregado de trióxido mineral _ comparado ao hidróxido de cálcio em pulpotomias. Histológico em dentes de cães. (Tese de Titular). Brazil: Faculdade de Odontologia, UFSC; 1996.

114- Souza V, Holland R, Holland-Jr C, Nery MJ. Estudo morfológico do comportamento da polpa dentária após pulpotomia e proteção com óxido de magnésio ou hidróxido de cálcio. O Incisivo 1972; 1:18-21.

115- Stanley HR. Calcium hydroxide and vital pulp therapy. In: Hargreaves KM, Goodis HE. Seltzer and Bender's dental pulp. Qintessence books: Chicago; 2002. p.309-24.

116- Stanley HR, Pameijer CH. Dentistry's friend: calcium hydroxide. Operat Dent 1997; 22:1-3.

117- Sydney GB. Identificação da microflora endodôntica após o preparo do canal radicular de dentes portadores de periodontite apical assintomática e o emprego de medicação de hidróxido de cálcio em diferentes tempos. (Tese de Doutorado). São Paulo: Faculdade de Odontologia da USP; 1996. 136p.

118- Thompson SW, Hunt RD. Selected histochemical and histopathological methods. Flórida: Charles C Thomas; 1966. p.615-46. 
119- Torabinejad M, Hong CU, Lee SJ, Monsef M, Pitt Ford TR. Investigation of mineral trioxide aggregate for root-end filling in dogs. J Endod 1995; 21:603-08.

120- Torabinejad M, Watson TF, Pitt Ford TR. Sealing ability of a mineral trioxide aggregate when used as a root end filling material. J Endod 1993; 19:591-95.

121- Tronstad L, Andreassen JO, Hasselgren G, Kristerson L, Riis I. $\mathrm{pH}$ changes in dental tissues after root canal filling with calcium hydroxide. J Endod 1981; 7:17-21.

122- Trope M, Delano O, Ørstavik D. Endodontic treatment of teeth with apical periodontitis: single vs. multivisit treatment. J Endod 1999; 25:345-50.

123- Wucherpfenning AL, Green DB. Mineral trioxide vs Portland cement: two biocompatible filling materials. J Endod 1999; 25:308 (abstract).

\section{Correspondence:}

Prof. Carlos Estrela

ADDRESS: Centro de Ensino e Pesquisa Odontológica (CEPO)

Rua B-1, Quadra 6, Lote 2, Setor Bueno, Goiânia, GO

CEP: 74.210 -108, e-mail: estrela3@terra.com.br

Brazil 